\title{
What Shapes Perceptions of the Federal Court System?
}

\author{
Theodore Eisenberg \& Stewart J. Schwab†
}

Two hundred years is a long time. It is too long after formation of a court system to ask such basic questions as (1) what cases occupy the system, and (2) whether even informed professionals have a reasonable picture of what goes on within the system. Nonetheless, continuing debate about the volume and makeup of litigation in general and of federal court litigation in particular requires legal scholars to address these questions. ${ }^{1}$ Professor Marc Galanter's work on the litigation explosion questions central assumptions about the nature and growth of the federal docket. ${ }^{2}$ Our prior work undermines widely held views about constitutional tort litigation, the effect of the civil rights fee-shifting statute, and prisoner constitutional tort litigation. ${ }^{3}$ Yet observers continue to note the many constitutional tort actions, describing them as "an ever more powerful tool" for challenging official action ${ }^{4}$ and noting an

† Professors of Law, Cornell Law School. Some of the data used in this article were gathered with financial support from National Science Foundation Grant No. SES-8510284. We wish to thank Kevin Clermont and participants at a Syracuse University College of Law faculty seminar for their comments and Jessica Murray, Neil Whoriskey, Kristin Tess and Karen Wilson for their assistance.

1 See, for example, Harry T. Edwards, The Role of Legal Education in Shaping the Profession, 38 J Legal Educ 285 (1988); Thomas B. Marvell, Caseload Growth-Past and Future Trends, 71 Judicature 151 (1987); Henry J. Reske, Was There a Liability Crisis?, 75 ABA J 46 (Jan 1989); Richard B. Schmitt, Survey Questions Liability Crisis At U.S. Companies, Wall St J B7 (Jan 18, 1989).

2 Marc Galanter, The Day After the Litigation Explosion, 46 Md L Rev 3 (1986); Marc Galanter, Reading the Landscape of Disputes: What We Know and Don't Know (And Think We Know) About Our Allegedly Contentious and Litigious Society, 31 UCLA L Rev 4 (1983).

3 Theodore Eisenberg \& Stewart J. Schwab, The Reality of Constitutional Tort Litigation, 72 Cornell L Rev 641 (1987); Stewart J. Schwab \& Theodore Eisenberg, Explaining Constitutional Tort Litigation: The Influence of the Attorney Fees Statute and the Government as Defendant, 73 Cornell L Rev 719 (1988).

Constitutional tort litigation consists of civil actions brought against state and local officials under 42 USC $\$ 1983$ and civil actions brought against federal officials based on Bivens $v$ Six Unknown Fed. Narcotics Agents, 403 US 388 (1971).

- Linda Greenhouse, 1871 Civil Rights Law Now Used for Many Causes, NY Times B6, col 3 (Aug 26, 1988). 
"explosion" in new uses of section 1983. "The section is "swamping the federal courts" and expediting the financial decay facing many local governments. ${ }^{\circ}$ And respected judges and commentators fervently argue that the caseload is smothering the courts. ${ }^{7}$ Judge Harry Edwards and some of his judicial colleagues have "the feeling that our friends in the law schools [do] not really understand the problems facing the judiciary ...."

Plainly, interested observers of the system have radically different views of litigation reality. This article explores why this might be so. For example, why is it that we cannot identify a civil rights explosion when judges and others perceive one? ${ }^{9}$ How can a Supreme Court Justice announce a geometric increase in civil rights litigation after enactment of a fee-shifting statute ${ }^{10}$ at a time when there was little support for even arithmetic growth? ${ }^{11}$ Why is it that some observers suspect that constitutional tort litigation is highly successful ${ }^{12}$ when, by most tangible measures, it is one of the less successful classes of federal litigation? ${ }^{13}$

\section{INTRODUCTION AND SUmmaRY}

To explore the puzzling variety of views of the federal court system, it is helpful to identify different outlooks on that system. This article provides an empirical perspective on appellate litigation to supplement an earlier district court study of constitutional tort litigation. ${ }^{14}$ The appellate study allows examination of questions that are of interest in their own right, but that also aid in assessing different perceptions of the federal courts. First, what does constitutional tort litigation look like on appeal and how does

- Andrew Blum, Lawsuits Put Strain on City Budgets, Natl L J 1 (May 16, 1988).

- Id.

7 See, for example, Edwards, $38 \mathrm{~J}$ Legal Educ at 286 (cited in note 1); Richard A. Posner, The Federal Courts: Crisis and Reform 63-65 (Harvard, 1985).

${ }^{8}$ Edwards, $38 \mathrm{~J}$ Leg Educ at 285 (cited in note 1).

O On judicial perception of constitutional tort litigation, see Eisenberg \& Schwab, 72 Cornell $L$ Rev at 646-50 (cited in note 3). For continuing discussion of the volume of constitutional tort litigation, see Greenhouse, NY Times at B6 (Aug 26, 1988) (cited in note 4).

${ }^{10}$ Pulliam v Allen, 466 US 522, 555-56 (1984) (Powell dissenting).

11 Eisenberg \& Schwab, 72 Cornell L Rev at 666 (cited in note 3); Schwab \& Eisenberg, 73 Cornell L Rev at 756-59 (cited in note 3).

12 Eisenberg \& Schwab, 72 Cornell $\mathrm{L}$ Rev at $651 \mathrm{n} 55$ (cited in note 3).

13 Theodore Eisenberg, Litigation Models \& Trial Outcomes in Civil Rights and Prisoner Cases, 77 Georgetown L J - (1989) (forthcoming); Eisenberg \& Schwab, 72 Cornell L Rev at 674 (Table VIII) (cited in note 3); Schwab \& Eisenberg, 73 Cornell L Rev at 733 (Table IV) (cited in note 3).

${ }^{14}$ Eisenberg \& Schwab, 72 Cornell L Rev 641 (cited in note 3); Schwab \& Eisenberg, 73 Cornell L Rev 719 (cited in note 3). 
it differ from other appellate litigation? Second, how does it differ from constitutional tort litigation at the district court level?

Consider three observers of the system. The first obtains information about the system from published appellate ${ }^{15}$ opinions. Many, even most, nonjudicial observers of the system know only what they read in published opinions. Most law students, law professors, and non-litigator lawyers fit into this category. ${ }^{16}$ They know little about the detailed breakdown of case filings in district court and have little direct information about the outcome of litigation at anything other than the appellate level. Moreover, even at the appellate level, detailed systematic information about cases resolved without opinion rarely finds its way into public news channels.

The second observer might be an appellate judge, who sees all filed appeals and indeed decides which appellate opinions should be published. The appellate judge, by reviewing district court judgments, has a window on litigation at the trial court level, but the perspective is likely to differ from that of the district court judge. The third observer is the district court judge, who sees all filings and has a ground level view of litigation.

Our central purpose is to see to what extent the perspectives of these three heroic observers will differ. The observers are not ordinary, for each has extraordinary vision. The law professor knows and accurately weighs all published appellate opinions; the appellate judge considers every filed appeal; and the district court judge keeps sight of every filing. Will their observations differ? Legal realists and others believe that published opinions are a skewed subset of filed cases, so finding some differences should not be surprising. ${ }^{17}$ The point is not that one perspective is more correct than any other. Certainly the district court judge sees the bulk of litigation, but perhaps loses the forest for the trees. Arguments can be made, and most law school casebook teaching is based on the supposition, that published appellate opinions convey the most accurate view of what the law is. Our objective is to assess how these three heroic observers might view constitutional tort litigation differently. Based on this assessment, our study suggests that differ-

1s We did not include district court opinions in this survey. See text at note 34 for an explanation.

18 The informed lay public probably derives much of their information of the legal system through published opinions as well, though derivatively as legal journalists report the results of cases.

${ }^{17}$ See, for example, George L. Priest \& Benjamin Klein, The Selection of Disputes for Litigation, $13 \mathrm{~J}$ Legal Stud 1 (1984). 
ent sources of information about litigation partly explain the radically different perceptions of constitutional tort litigation.

Briefly summarized, we find that different stages in federal court litigation lead to different impressions of the volume and nature of federal litigation. With respect to the number of cases, the observers whose perceptions of the federal court system are shaped by reading published appellate opinions or by judging appellate filings would detect a much higher volume of nonprisoner constitutional tort litigation relative to other forms of litigation than would the observer of cases filed at the district court level. ${ }^{18} \mathrm{~A}$ plausible hypothesis about the overestimation of the volume of district court constitutional tort litigation is that many observers see or read about the many published appellate opinions without any systematic sense of the characteristics of filed district court cases.

With respect to the outcome of litigation, the reader of published appellate opinions would also have a substantially different impression of constitutional tort litigation than would the observer of filed cases. We take two distinct approaches. First, we focus on the actual outcomes in each stage of litigation, comparing the success of constitutional tort plaintiffs in district court with their success on appeal. Constitutional tort plaintiffs are substantially more successful at the appellate level than at the district court level. ${ }^{19}$ Thus to the extent published appellate opinions shape views of the court system, observers would believe constitutional tort litigation is more successful than it really is at the trial court level.

Our second approach reinforces the inflated perception of success. We examine published opinions not only for what they tell about the outcome of the appellate process, but also for the story they tell about what went on below. For many observers the dominant source of information about the outcome of trials is, once again, published appellate opinions. Ignoring the outcome of the appeal, what impression of district court constitutional tort litigation do published appellate opinions create, and how does that impression differ from what our idealized district court observer perceives? Briefly, we find that the cases that lead to published appellate opinions are, at the district court level, a highly successful subset of all filed cases, with a different distribution of subject matter and procedural progress. ${ }^{20}$

After describing the nature of the studies conducted, and their

\footnotetext{
18 See text at notes 58-62.

${ }^{19}$ See text at notes $63-68$ and Table III.

${ }^{20}$ See text at notes 76-79 and Table IV.
} 
limitations, we present the results of the appellate study. We then contrast the appellate results with the district court results. Finally, we return to the question of what shapes the differing views of the legal system.

Two limitations should be highlighted. First, study of one area of federal litigation, constitutional tort cases, can provide only limited insight into other areas of litigation. Nevertheless, the area is important even though one must be wary of extrapolating our findings to other areas. If one is going to study the federal court system on the occasion of its bicentennial, there could hardly be a more appropriate class of cases to study than constitutional tort cases. They, as much as any class of cases, show the federal courts at work in what has become their central role as guardians of civil liberty. As this and other studies show, constitutional tort cases also comprise a substantial portion of the workload of both the federal courts of appeals and the federal district courts.

Second, the questions of court caseload and case outcome encompass many different nuances that we deliberately ignore. The court system is ever changing. However large the federal district court docket has grown in the past thirty years, ${ }^{21}$ that growth is dwarfed by the growth rate of the appellate docket. ${ }^{22}$ The Supreme Court's workload has become an area of study unto itself. ${ }^{23}$ Also, the real world observers of the system, whose perceptions we try to capture, include many different groups-lawyers, district court judges, courts of appeals judges, academics, and policymakers. Within these groups there are important differences in the sources of perceptions. District judges in the Eastern District of Virginia or the Middle District of Florida, which often are among the leading districts in prisoner civil rights filings, ${ }^{24}$ probably have a very different perspective on the federal caseload than does a judge in a district not fed by prisoner civil rights petitions. Appellate courts have long been recognized as having different characteristics and as engaging in different interactions than trial courts. ${ }^{25}$ And within

21 Posner, The Federal Courts at 62-65 (cited in note 7).

22 Id.

${ }^{23}$ See, for example, Samuel Estreicher \& John Sexton, Redefining the Supreme Court's Role (Yale, 1986); Gerhard Casper \& Richard A. Posner, The Workload of the Supreme Court (Am Bar Found, 1976).

24 Administrative Office of the U.S. Courts, 1986 Annual Report of the Director 181-88 (Table C 3) (GPO, 1986); Administrative Office of the U.S. Courts, 1984 Annual Report of the Director 265-263 (Table C 3) (GPO, 1984); Administrative Office of the U.S. Courts, 1983 Annual Report of the Director 248-55 (Table C 3) (GPO, 1983).

${ }^{23}$ See Sheldon Goldman \& Charles M. Lamb, eds, Judicial Conflict and Consensus: Behavioral Studies of American Appellate Courts (U Kentucky, 1986); J. Woodford How- 
the appellate courts, the judges of the D.C. Circuit Court of Appeals write opinions that are twice as long as those issued in other circuits, containing more than six times the number of footnotes, ${ }^{26}$ with a unique subject matter workload. ${ }^{27}$ Regardless of the cause or justifiability of the longer opinions, these judges' views on the nature of the workload may differ from those of judges in other circuits. Thus, even if we successfully identify different sources of perceptions about constitutional tort cases, directly linking the different perspectives to a specific group's perceptions (as if any of those groups had a single perception of the system) would be difficult. We must settle for idealized groupings and simplified categories. If we begin to make the different perceptions of the system-and their causes-part of the serious debate about federal court litigation we will have accomplished our task.

\section{The District and Appellate Court Studies}

The results discussed here stem from data gathered in two studies, one of federal district court filings and one of opinions published by federal courts of appeals. In addition, we use data on district court and appellate filings published by the Administrative Office of the United States Courts to help assess the relative burden of constitutional tort litigation on district and appellate dockets.

\section{A. The District Court Study}

The district court study, described in greater detail in earlier work, ${ }^{28}$ includes data on nearly every nonprisoner and prisoner constitutional tort case filed from October 1, 1980 to September 30,1981 in three major federal districts. The districts covered are the Central District of California, which includes Los Angeles, the Eastern District of Pennsylvania, which includes Philadelphia, and the Northern District of Georgia, which includes Atlanta. Together these districts comprised 8.6 percent of the 1980 United States population, ${ }^{29}$ and, in 1981, their dockets accounted for 8.1 percent

ard, Jr., Courts of Appeals in the Federal Judicial System (Princeton, 1981).

${ }^{28}$ Posner, Federal Courts at 118 (Table 4.4) (cited in note 7).

${ }_{27}$ Howard, Courts of Appeals at 30 (Table 2.4) (cited in note 25).

${ }^{28}$ Eisenberg \& Schwab, 72 Cornell L Rev 641 (cited in note 3); Schwab \& Eisenberg, 73 Cornell L Rev 719 (cited in note 3).

${ }^{28}$ The Administrative Office of the U.S. Courts, using preliminary census data, reported the 1980 population of the three districts as: 11,950,211 (Central District of California), 5,017,194 (Eastern District of Pennsylvania), 2,895,912 (Northern District of Georgia). 
of all federal nonbankruptcy civil filings, 7.9 percent of all nonprisoner civil rights filings, and 4.2 percent of all prisoner civil rights filings. ${ }^{30}$ For comparison the district court study also includes a randomly selected sample of all non-civil-rights civil filings in the same districts.

\section{B. The Appellate Court Study}

The appellate court study covers published opinions from the Third, Ninth, and Eleventh federal circuit courts of appeals, the circuits encompassing the three districts in the district court study. $^{31}$ It examines opinions published from October 1, 1980 to December 31, 1985. It thus includes the time period covered by the district court study but, to assure a sufficiently large sample for our purposes, covers a longer period of time. Appellate opinions are not generated as quickly as district court filings. At the appellate level, as at the district level, we divided the universe of cases into constitutional tort cases and a control group of non-civilrights cases. We tried to include every constitutional tort case that resulted in a published opinion during the period, though we doubt that the results would change significantly if some opinions were not found. ${ }^{32}$ In total, we gathered 771 published constitutional tort

Administrative Office of the U.S. Courts, Federal Judicial Workload Statistics During the Twelve-Month Period Ended December 31, 1981 A-92 (Table X-10) (Statistical Analysis \& Reports Division, 1982). The combined population figure for the three districts is $19,863,317$. The same data show the total U.S. population to be $229,910,565$. Other reports of census data differ slightly from these figures.

so Administrative Office of the U.S. Courts, 1986 Annual Report of the Director 369373 (GPO, 1981). These figures are for a twelve month period slightly different than that used in the field portion of this study. The relatively low percentage of prisoner civil rights filings represented by the three districts is in part a consequence of the bunching of prisoner civil rights filings in a few districts. For example, the Eastern District of Virginia and the Middle District of Florida had, respectively, 8.3 percent and 5.8 percent of all prisoner civil rights filings for the period.

${ }^{31}$ The old Fifth Circuit was divided into a new Fifth Circuit and the current Eleventh Circuit during this time. The Northern District of Georgia had been part of the old Fifth Circuit but is now part of the Eleventh Circuit. In an effort to keep some minimal tie to the district court regions studied, we include Fifth Circuit cases from before the breakup and Eleventh Circuit cases after the breakup.

32 The Westlaw search used was:

“((42 + S 1983) (1983 \& CIVIL + S RIGHT) BIVENS) \& DATE(AFTER 9/30/80 \& BEFORE 1/1/86)"

This search provided a list of cases that was vastly overinclusive in that it included many non-constitutonal-tort cases. They were eliminated. Although there may be some constitutional tort cases missed by the search, it should pick up every Westlaw case citing $\S 1983$ or mentioning Bivens. Of course, there is no requirement that all "published" opinions show up in Westlaw. And there are known differences among Administrative Office publication figures, Westlaw figures, and Lexis figures. See Peter W. Martin, Memorandum to Donna 
appellate opinions. From the non-civil-rights category of published opinions, we extracted a random sample sufficiently large to assure statistical representativeness (760 opinions). ${ }^{33}$

We recognize the possibility of monitoring district court published opinions as well as or instead of appellate level published opinions. However, there are several drawbacks to using district court opinions. First, no individual district issues a substantial number of constitutional tort opinions in a year. Second, district court judges, even more than appellate judges, may decide to publish opinions in skewed samples of cases. Professor Franklin's study of First Amendment litigation suggests that trial judges are more likely to publish opinions when making decisions that conclude cases, such as granting motions to dismiss or granting summary judgment rather than when denying such motions. ${ }^{34}$ Third, in testing impressions about the litigation system, it is more realistic to study appellate opinions. In general, they are likely to be more widely read than district court opinions and have a greater precedential value.

\section{Limitations of the Studies}

Ideally, one would study all district court filings and all court of appeals opinions to determine whether they project different pictures of litigation. The comprehensiveness of such data would assure representativeness. Time and resources restrict the studies used here to more limited times and places. Although the district court and published opinion samples are related, the studies can be thought of as two substantial studies of litigation, conducted largely independently of one another. We use the district court study to assess the impression of litigation generated by filings and the appellate study to assess the impression of litigation generated

Stienstra, Stewart Schwab, Ted Eisenberg and Other Interested Folks, (March 6, 1987) (on file with the University of Chicago Law Review).

${ }^{33}$ We tried to uncover every case for which Westlaw reports a published opinion for the period covered. We then randomly sampled each circuit and eliminated criminal cases and civil rights cases from the control group. The net result yielded 956 control group cases, 196 of which were agency cases. We limit the study to civil appeals and thus exclude the agency cases, leaving a sample of 760 cases. The 760 sampled opinions are drawn from a population of 4,765 possible control group opinions. See note 42 . The sample size is large enough to assure that a 95 percent confidence interval is within .06 of the sample mean. For an estimate of the completeness of the study see note 43 . We also exclude from the control group civil rights and prisoner cases that are not constitutional tort cases.

34 Marc A. Franklin, Suing Media for Libel: A Litigation Study, 1981 Am Bar Found Res J 797, 799 n 11; Marc A. Franklin, Winners and Losers and Why: A Study of Defamation Litigation, 1980 Am Bar Found Res J 455, 464. 
by published opinions.

Because the data used are not comprehensive, the figures derived from them may have shortcomings. The impression conveyed by the cases filed in all the district courts within the three circuits might differ from the impression conveyed by the cases filed in the three districts studied. Similarly, the portrayal of litigation by cases appealed from the three districts might differ from that of litigation embodied in the appeals studied in the three circuits as a whole. In addition, it may be that both the district courts and circuit courts studied are not typical of other districts and circuits.

Despite these problems, several factors suggest that the results presented here are meaningful, if not conclusive. First, the samples studied are large enough on their own to warrant attention. At the appellate level the study encompasses more than five years of opinions in one-quarter of the regular courts of appeals. These results are important even if they are not wholly representative. It is unlikely that the impression conveyed by such a large group of cases is wildly unrepresentative of the larger litigation reality. The sample at the district court level is also large enough to be significant by itself. However, since the sample covers only one year, there is a greater risk that it does not accurately represent constitutional tort litigation or non-civil-rights litigation over time. Still, in its major conclusions offered about success and burden on the courts, the one year study is reinforced by an earlier study of constitutional tort litigation $^{35}$ and by other studies of non-civil-rights litigation. ${ }^{36}$

Second, both samples contain a reasonable amount of geographical diversity. The district court sample includes three large districts representing the East coast, the West coast, and the South. The appellate study includes important eastern, western, and southern circuits. The district court sample does, however, overemphasize urban districts at the expense of rural districts.

Third, for purposes of comparing the relative volume of civil rights litigation on appeal and at the district court level, we rely not on samples but on the complete set of national data published by the Administrative Office. Unfortunately, the data do not include a separate category for constitutional tort litigation and they have other drawbacks for study of constitutional tort litigation. ${ }^{37}$

3s Theodore Eisenberg, Section 1983: Doctrinal Foundations and an Empirical Study, 67 Cornell L Rev 482 (1982).

${ }^{36}$ Schwab \& Eisenberg, 73 Cornell L Rev at 729 n 36 (cited in note 3) (reviewing other studies).

${ }^{37}$ Eisenberg \& Schwab, 72 Cornell L Rev at 662-68 (cited in note 3) (detailing the 
Still, it is the most complete and widely relied upon set of data about the federal court system.

\section{Constitutional Tort Litigation on Appeal}

This section examines the volume, success, and nature of constitutional tort litigation on appeal. Subsection A looks at appellate litigation by itself, comparing constitutional tort cases with the non-civil-rights cases in our control group. Subsection B then compares constitutional tort cases on appeal with constitutional tort cases in district court. Subsection C suggests how district court constitutional tort litigation appears through the lens of appellate opinions, and how this perception differs from the reality of constitutional tort litigation in the district courts.

\section{A. Constitutional Tort Appeals Compared with Non-Civil-Rights Appeals}

Two central concerns about constitutional tort litigation are its burden on the courts and the perceived impact of successful suits. $^{38}$ Particular classes of cases can burden the courts in several ways, including their fraction of the docket, their difficulty, and their time on the docket. By these measures, how does constitutional tort litigation differ from other litigation? Whether or not they are more burdensome, do constitutional tort cases fare better or worse than others? With the appellate level experience revealed, it is then possible to consider the different observers' pictures of constitutional tort litigation.

1. Burden as Measured by Fraction of the Appellate Docket and Published Opinions.

Although the Administrative Office does not separate out constitutional tort cases as a distinct category of appellate litigation, it provides broader civil rights litigation categories that encompass constitutional tort litigation and other civil rights cases. ${ }^{39}$ Table I

difficulties in relying on the Administrative Office data). See also note 39 (discussing Administrative Office case categories).

${ }^{38}$ Eisenberg \& Schwab, 72 Cornell L Rev at 644-52 (cited in note 3).

39 For the relationship between Administrative Office categories and constitutional tort litigation, see Eisenberg, 77 Georgetown L Rev at _ (cited in note 13); Eisenberg \& Schwab, 72 Cornell L Rev at 663-65 (cited in note 3); Schwab \& Eisenberg, 73 Cornell L Rev at 723$25,728-29 \mathrm{n} 34$ (cited in note 3 ). While these categories overstate the number of constitutional tort cases, they separate out the bulk of employment discrimination cases and prisoner habeas corpus filings. Furthermore, the Administrative Office appears to use the same 
presents Administrative Office filing data for the Administrative Office categories ("other civil rights" and "prisoner civil rights") that most nearly correspond to our categories of constitutional tort litigation. We sometimes refer to these Administrative Office categories as containing "possible constitutional tort" cases. The Table reports the nationwide total civil filings at the district and appellate level for each year, and the percentage of total filings consisting of "other civil rights" cases and "prisoner civil rights" cases. The appellate numbers and percentages are based on appeals of civil cases from district courts and do not include direct appellate review of agency action or appeals of criminal cases.

Table I

Possible Constitutional Tort Cases-Nationwide

Percentage of Appellate \& District Court Filings

\begin{tabular}{|c|c|c|c|c|c|c|}
\hline Year & $\begin{array}{l}\text { Court } \\
\text { Level }\end{array}$ & $\begin{array}{l}\text { Total } \\
\text { Civil } \\
\text { Filings }\end{array}$ & $\begin{array}{l}\text { Other } \\
\text { Civil } \\
\text { Rights }\end{array}$ & $\begin{array}{c}\text { Prisoner } \\
\text { Civil } \\
\text { Rights }\end{array}$ & $\begin{array}{c}\text { \% } \\
\text { Other Civil } \\
\text { Rights }\end{array}$ & $\begin{array}{c}\text { \% } \\
\text { Prisoner } \\
\text { Civ. Rights }\end{array}$ \\
\hline 1982 & appeals & 18,784 & 2,157 & 2,272 & $11.5 \%$ & $12.1 \%$ \\
\hline 1982 & district & 206,193 & 8,727 & 17,575 & $4.2 \%$ & $8.5 \%$ \\
\hline 1983 & appeals & 20,249 & 2,334 & 2,579 & $11.5 \%$ & $12.7 \%$ \\
\hline 1983 & district & 241,842 & 9,938 & 18,477 & $4.1 \%$ & $7.6 \%$ \\
\hline 1984 & appeals & 21,725 & 2,474 & 3,090 & $11.4 \%$ & $14.2 \%$ \\
\hline 1984 & district & 261,485 & 10,738 & 18,856 & $4.1 \%$ & $7.2 \%$ \\
\hline 1985 & appeals & 23,571 & 2,768 & 3,060 & $11.7 \%$ & $13.0 \%$ \\
\hline 1985 & district & 273,670 & 10,757 & 19,448 & $3.9 \%$ & $7.1 \%$ \\
\hline 1986 & appeals & 24,291 & 2,889 & 3,306 & $11.9 \%$ & $13.6 \%$ \\
\hline 1986 & district & 254,828 & 10,366 & 20,842 & $4.1 \%$ & $8.2 \%$ \\
\hline 1987 & appeals & 25,538 & 2,977 & 4,166 & $11.7 \%$ & $16.3 \%$ \\
\hline 1987 & district & 238,982 & 10,105 & 23,697 & $4.2 \%$ & $9.9 \%$ \\
\hline Total & appeals & 134,158 & 15,599 & 18,473 & $11.6 \%$ & $13.8 \%$ \\
\hline '82-87 & district & $1,477,000$ & 60,631 & 118,895 & $4.1 \%$ & $8.0 \%$ \\
\hline
\end{tabular}

Source: Administrative Office Annual Reports, Tables B-1A and C-2 $2^{40}$

terminology to describe two slightly different categories. At the district court level, the category "other civil rights" does not include cases classified under three additional civil rights headings, "voting," "accommodations," and "welfare." These categories are listed separately in the Annual Reports cited in note 40. At the appellate level, the Annual Reports incorporate these three categories into the larger category "other civil rights," even though the Administrative Office computer tapes contain the necessary appellate data in each of the three subcategories. See note 43 . The distortion introduced by combining the categories is not substantial because together the three categories account for a relatively small percentage of civil rights activity. See note 43 . (showing 75 cases in these three categories and 1,184 cases in what we call the possible constitutional tort categories).

10 Administrative Office of the U.S. Courts, 1982 Annual Report of the Director 194 
Table I shows that "other civil rights" and "prisoner civil rights" cases constitute a substantial fraction of the appellate docket. The combined prisoner and nonprisoner ("other civil rights") possible constitutional tort categories range from about 24 percent to about 28 percent of all appellate review of district court civil judgments. To obtain an estimate of actual constitutional tort cases on appeal, one should discount the Administrative Office figures by the degree to which they include non-constitutional civil rights claims. Using discount factors developed in our district court study, this suggests that approximately 21 percent of all civil appeals from federal district courts are constitutional tort cases. ${ }^{41}$

Table I also suggests that nearly as many appeals are filed in nonprisoner cases $(15,599)$ as in prisoner cases $(18,473)$. By contrast, at the district court level prisoners file almost twice as many possible constitutional tort complaints as do nonprisoners.

Only appellate judges and other court personnel see the bulk of filed appeals. Most other observers see only those appeals leading to published opinions. Because we need not depend on Administrative Office data to detect published opinions, the published opinion study enables us to focus more precisely on actual constitutional tort cases as a percentage of all published opinions. We find, in the three studied circuits, 771 constitutional tort opinions, with 604 nonprisoner opinions and 167 prisoner opinions. We estimate that the three circuits published a total of 6,287 civil opinions during this period. ${ }^{42}$ Thus constitutional tort cases comprised

(Table B-1A); 216 (Table C-2) (GPO, 1982); Administrative Office of the U.S. Courts, 1983 Annual Report of the Director 224 (Table B-1A); 246 (Table C-2) (GPO, 1983); Administrative Office of the U.S. Courts, 1984 Annual Report of the Director 232 (Table B-1A); 254 (Table C-2) (GPO, 1984); Administrative Office of the U.S. Courts, 1985 Annual Report of the Director 248 (Table B-1A); 280 (Table C-2) (GPO, 1985); Administrative Office of the U.S. Courts, 1986 Annual Report of the Director 142 (Table B-1A); 176 (Table C-2) (GPO, 1986); Administrative Office of the U.S. Courts, 1987 Annual Report of the Director 142 (Table B-1A); 177 (Table C-2) (GPO, 1987).

11 Our district court study found that 74 percent of the cases listed by the Administrative Office as "other civil rights" are constitutional tort cases, and 89 percent of the cases listed as "prisoner civil rights" cases are constitutional tort cases (the other cases having solely statutory claims). See Schwab \& Eisenberg, 73 Cornell L Rev at 725 (Table I) (cited in note 3). If we assume that equal proportions of constitutional and statutory civil rights cases are appealed, one can discount the appellate categories by these district court discount factors. Doing so suggests that appellants in 1982-87 filed appeals in $(.74 \times 15,599)$ nonprisoner constitutional tort cases and $(.89 \times 18,473)$ prisoner constitutional tort cases. The 27,984 nonprisoner and prisoner constitutional tort appeals are 20.9 percent of all civil appellate filings from district court judgments.

42 To construct the control group, we used a Westlaw search designed to capture all published opinions other than those that might be constitutional tort cases. From this list, we sampled every eighth case in the Ninth and Eleventh Circuits and every third case in the 
about 12.3 percent of all published opinions in the three circuits, with over three-quarters (78 percent) of them involving nonprisoner cases. $^{43}$ In comparison, other tort litigation comprised

Third Circuit. Criminal and agency appeals were then removed from the initial sample. With these exclusions the Ninth Circuit sample yielded 257 published opinions. To estimate the total number of civil opinions filed in the Circuit, we multiplied this by eight, the inverse of the one-eighth sampling ratio, yielding 2,056 published opinions for this circuit. Similar calculations for the other circuits yield 1,920 published opinions for the Eleventh Circuit and 789 published opinions for the Third Circuit. We add two classes of cases to this total of 4,765 opinions. The first is the 771 constitutional tort cases. The second is the 751 cases found in the constitutional tort search that turned out not to be decisions about constitutional tort litigation, which we also use as a crude estimate of nonconstitutional tort civil rights litigation. This leads to an estimate of total civil opinions available on Westlaw of 6,287 . The control group is weighted to reflect the fact that the sample contains different proportions of the published opinion population for the three circuits.

43 Recently available data on federal appeals allows an estimate of the study's completeness. The Administrative Office of the United States Courts and the Federal Judicial Center have prepared computer tapes containing data on all federal appeals. We extracted from those tapes all civil appeals (thus excluding criminal appeals and agency-related appeals) for the three circuits for the time period covered by this study. The tapes show 8,202 possible civil, nonagency-related published opinions for the three circuits during the period studied. The Administrative Office civil rights categories that might yield constitutional tort cases show the following numbers of published opinions:

other civil rights (code 440)

actual

estimated

other civil rights
voting (code 441)

866

40

jobs (code 442)

accommodations (code 443)

22

welfare (code 444)

13

318

prisoner civil rights (code 550)

total estimated

We discount the actual figures by the yield of true constitutional tort cases in each category from our district court experience, yielding the parenthetical figures shown next to the actual figures. See Schwab \& Eisenberg, 73 Cornell L Rev at 725 (Table I) (cited in note 3). The result is an estimated total of 1,080 constitutional tort published opinions or 13.2 percent of the total published opinions, with nonprisoner constitutional tort cases comprising 9.7 percent of published opinions and prisoner cases comprising 3.45 percent.

The ratios from our Westlaw searches given in the text, 12.3 percent for the combined constitutional tort category, 9.6 percent for the nonprisoner category, and 2.7 percent for the prisoner constitutional tort category are reasonably close to the Administrative Office data. The only substantial difference is in the relatively low number of prisoner cases found in the Westlaw search. To the extent the Administrative Office label of "published" does not match what appears on Westlaw, the difference probably does not dramatically distort the relative number of constitutional tort cases as compared with other civil cases. See also Posner, Federal Courts at 70-72 (Table 3.5) (cited in note 7) (finding, using slightly different categories, that civil rights cases are 14 percent of signed civil opinions).

One might reduce the disparity between the number of opinions found and the number of cases the Administrative Office lists as published by excluding "unsigned" opinions from the totals. Of the 8,202 total published opinions shown on the tapes, 910 opinions are designated "unsigned" and 236 of these are in the civil rights categories of interest here. See also note 32. A complete description of Administrative Office data appears in Inter-university 
about 13.8 percent of the published opinions of appeals from district courts. ${ }^{44}$

As Figure 1 summarizes, appellate judges in these three circuits publish about the same percentage of nonprisoner constitutional tort opinions as they receive from district courts, about 10 percent. ${ }^{45}$ Thus, the picture from published opinions is similar to the picture from appellate filings. By contrast, prisoner constitutional tort cases would seem like a much less important category if one views opinions rather than appellate filings. They comprise less than 3 percent of all published civil opinions (167 of 6,287), but over 12 percent of the appellate filings. The hidden prisoner cases perhaps explain why judges seem to complain relatively more about prisoner cases.

\section{Figure 1}

\section{Constit. Tort Cases: Percent of Docket District Court Filings, Appellate Filings, Appellate Opinions}

Percent

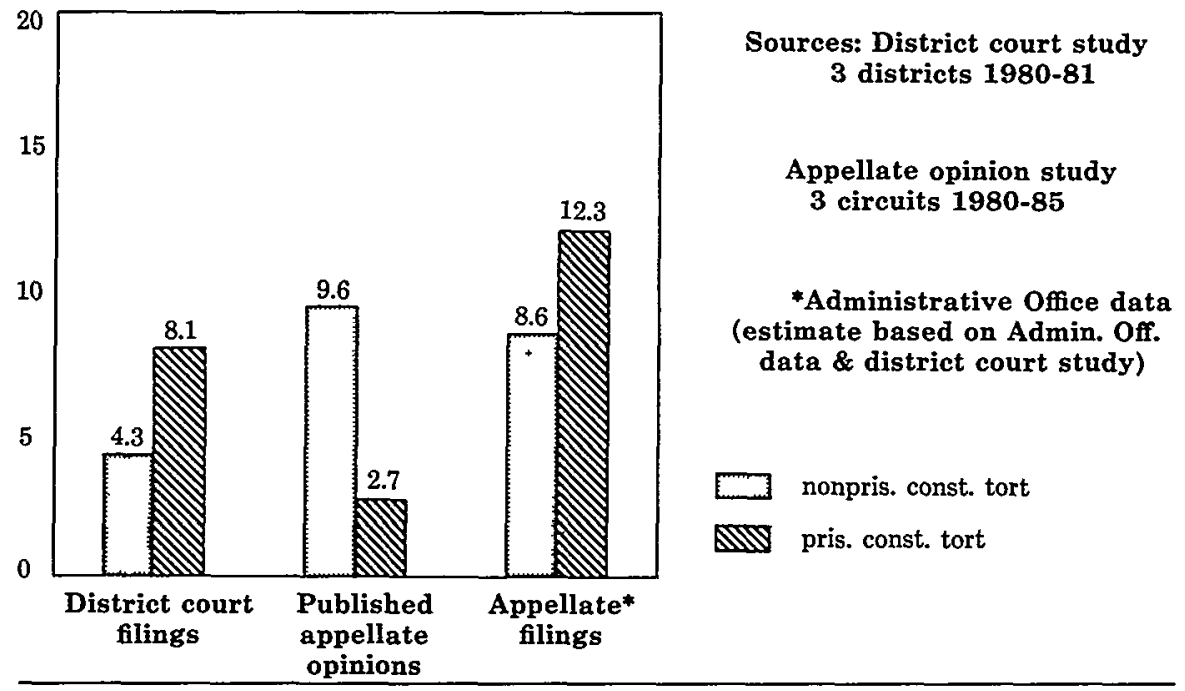

Consortium for Political and Social Research (Federal Judicial Center, Principal Investigator), Federal Court Cases: Integrated Data Base, 1970-1987, ICPSR 8429 (Winter 1989). For calculations in this note involving Administrative Office data we used Fifth Circuit cases from 10/1/80 to 6/30/82 and Eleventh Circuit cases thereafter.

14 This figure is based on our random sample of non-civil-rights published opinions.

${ }^{45}$ One must be cautious about this comparison, because the figures are from different data sets. The percentage of constitutional tort filings on appeal comes from nationwide Administrative Office data comparing the "other civil rights" category to all civil non-agency appellate filings, discounted by figures developed in our study of district court litigation. See note 41 . The percentage of nonprisoner constitutional tort published opinions comes from our own examination of opinions in the three circuits. 


\section{Burden as Measured by Difficulty.}

Published opinions suggest that constitutional tort appeals are about as difficult to resolve as other appeals, although the evidence is somewhat conflicting with respect to prisoner constitutional tort appeals. One measure of difficulty is how often the appellate court hears oral argument in a class of cases. In our study, the Third and Ninth Circuits ${ }^{46}$ heard argument in 86.6 percent of the nonprisoner constitutional tort cases in which they published opinions and 67.8 percent of the non-civil-rights cases in which they published opinions. ${ }^{47}$ Prisoner constitutional tort opinions are more similar to non-civil-rights opinions in the likelihood of oral argument. The appellate courts heard argument in only 62.6 percent of the prisoner constitutional tort cases in which they published opinions. ${ }^{48}$

A second measure of an area's difficulty is the degree to which appellate panels decide cases unanimously. Our study reveals no statistically significant difference between constitutional tort opinions and non-civil-rights opinions in this regard. Dissents appear in 10.3 percent of the nonprisoner constitutional tort opinions, 11.4 percent of the prisoner constitutional tort opinions, and 8.3 percent of the non-civil-rights opinions. Judges do appear to write significantly more concurring opinions in nonprisoner constitutional tort cases than in non-civil-rights cases. They wrote concurrences in 54 of the 604 nonprisoner constitutional tort opinions (8.9 percent), while writing only 37 concurrences in the sample of 760 noncivil-rights opinions ( 4.9 percent). ${ }^{48}$ The propensity to write concurrences does not appear in prisoner constitutional tort cases. Judges wrote concurrences in only 9 of 167 prisoner cases (5.4 percent) barely and statistically insignificantly higher than the rate of concurrences in non-civil-rights cases.

A third measure might be the percentage of published opinions that are issued per curiam rather than signed by a judge. Generally, the more trivial cases are handled with per curiam opinions. In nonprisoner constitutional tort cases, the three circuits issued per curiam opinions in 18.2 percent ( 110 of 604 ) of the cases and in

16 The Eleventh Circuit does not indicate in its published opinions whether or when it heard oral argument in a case. Thus, all figures about percentage of cases argued and time to disposition relate only to the Third and Ninth Circuits.

${ }^{47}$ With 306 nonprisoner constitutional tort opinions and 561 non-civil-rights opinions, this difference in likelihood of oral argument is statistically significant at the .0000 level.

48 With 91 nonprisoner constitutional tort opinions for which data about argument were available, this modest difference is statistically insignificant.

40 This difference is significant at the .01 level. 
prisoner constitutional tort cases they issued per curiam opinions in 29.9 percent (50 of 167 ) of the cases. In contrast, the appellate courts issued per curiam opinions in 17.5 percent (133 of 760) of non-civil-rights appeals, nearly identical to the rate of per curiam opinions in nonprisoner constitutional tort cases but significantly less than the rate in prisoner cases.

A final measure of difficulty is the amount of time the appellate judges take to decide appeals. The median time for publishing opinions after oral argument is virtually identical for constitutional tort and non-civil-rights cases. For opinions published after oral argument, the median time for publishing nonprisoner constitutional tort opinions was 119 days after argument, and the median prisoner case took 124 days. The median non-civil-rights opinion was published 112 days after argument. Courts published opinions more quickly in cases decided without oral argument, but again there is almost no difference between constitutional tort cases and other cases. The median time for nonprisoner constitutional tort opinions decided without oral argument was 73 days after submission, and for prisoner cases it was 72 days. The median non-civilrights opinion was published 75 days after submission without oral argument.

To summarize the measures of burden and difficulty of constitutional tort litigation on appeal, about one in eight opinions involve constitutional torts. Courts hear oral argument in constitutional tort cases more often than in other cases. Judges are slightly more likely to dissent in constitutional tort cases, and (for nonprisoner cases, at least) significantly more likely to write a concurring opinion. Judges take a similar amount of time to issue constitutional tort opinions (both prisoner and nonprisoner) as non-civilrights opinions, with a slightly higher fraction of constitutional tort opinions being issued per curiam. We conclude, based on these measures, that the burden of constitutional tort litigation on appeal comes from its substantial percentage of the docket, not from its being inherently more difficult litigation.

\section{Success of Constitutional Tort Plaintiffs.}

If the overall burden is one central concern about constitutional tort litigation, its perceived success for plaintiffs and impact on the court system is another. ${ }^{50}$ Are constitutional tort plaintiffs more or less successful than other litigants on appeal? Before pur-

${ }^{B 0}$ Eisenberg \& Schwab, 72 Cornell L Rev at 644-52 (cited in note 3). 
suing this question, it is necessary, as at the district court level, ${ }^{51}$ to discuss difficulties in measuring success.

In some ways, one can pronounce a winner or loser more confidently in appellate litigation resulting in a published opinion than in district court litigation. Most importantly, settled cases-with all their ambiguities about who "won"-are absent. Rather, a party appeals a judgment of the district court and the appellate court, as part of the published opinion, affirms or does not affirm the judgment. One can correspondingly designate the appellant as a loser or winner, and the appellee as a winner or loser. Complications arise when both parties appeal or when the appellate court affirms in part and reverses or remands in part. To avoid the ambiguity introduced by such outcomes, for purposes of analyzing success on appeal we limit the set of published opinion to those cases in which it is possible to say that either plaintiff or defendant prevailed on appeal.

Knowing only that the plaintiff or defendant prevailed on appeal, however, provides only part of the information necessary to decide who fares well at the appellate level. It is widely believed that appellate courts have a substantial tendency to affirm the decisions of lower courts. ${ }^{52}$ If this is true, one must account not only for whether the plaintiff or defendant prevailed on appeal but also for whether they sought affirmance or reversal of the district court's decision. Another problem is that limiting the analysis to published opinions may underestimate the tendency to affirm. Appellate courts do not publish routine affirmances, but will explain most reversals of lower court decisions. Thus, the published opinions may not reveal a tendency to affirm, even if one exists.

With these limitations in mind, Figure 2 shows how plaintiffs and defendants fare in published appeals in three categories of cases-constitutional tort, prisoner constitutional tort, and control group. The control group of non-civil-rights cases reveals a tendency to affirm district court judgments. The instances of affirmance are about equal when plaintiffs are appellants or appellees. Plaintiffs successfully appealed in 35 percent of the published cases in which they appealed (65 percent affirmance rate), while defendants successfully appealed in 33 percent of the published

s1 See Eisenberg \& Schwab, 72 Cornell L Rev at 676-77 (cited in note 3); Schwab \& Eisenberg, 73 Cornell L Rev at 726-28 (cited in note 3).

${ }^{32}$ Stanton Wheeler, Bliss Cartwright, Robert A. Kagan \& Lawrence M. Friedman, Do the "Haves" Come Out Ahead? Winning and Losing in State Supreme Courts, 1870-1970, 21 L \& Society Rev 403, 406-07 (1987). 
cases in which they appealed (67 percent affirmance rate). ${ }^{53}$

Figure 2

\section{Rate of Reversal by Party Appealing Constitutional Tort \& Control Group}

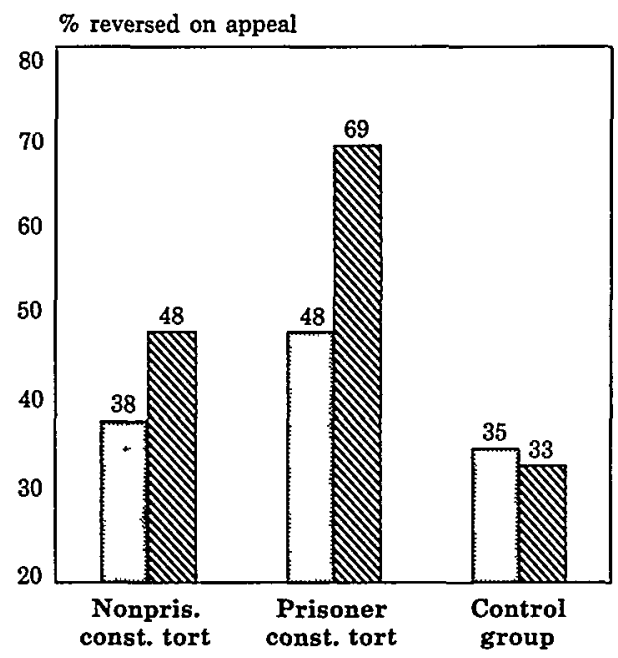

Source: published opinions 3 Circuits $10 / 1 / 80$ to $12 / 31 / 85$

In nonprisoner constitutional tort cases, the same affirmance effect appears when plaintiffs appeal. Nonprisoner constitutional tort plaintiffs prevailed in 38 percent of the published cases in which they appealed, a figure near the 35 percent reversal rate in the control group of non-civil-rights plaintiffs. The affirmance effect disappears almost entirely, however, when nonprisoner constitutional tort plaintiffs win below. Among the published appellate opinions reviewing judgments for the plaintiffs, defendants succeed in about half (48 percent) of the cases. ${ }^{54} \mathrm{~A}$ similar, though more dramatic, pattern holds for prisoner constitutional tort appeals. Among published opinions, plaintiffs overturned judgments in 48 percent of the cases they appealed, while defendants overturned

${ }^{83}$ The control group sample used in this calculation has 411 published opinions in which plaintiffs appealed and 222 in which defendants appealed. The difference in affirmance rates is not statistically significant at the .10 level.

s4 The 15 percent difference between nonprisoner constitutional tort defendants and non-civil-rights defendants in obtaining reversals is statistically significant at the .05 level. Among the reported opinions with clear outcomes, nonprisoner constitutional tort plaintiffs appealed 395 cases and defendants appealed 89 cases. 
judgments in 69 percent of the cases they appealed.55 Thus, among published opinions, constitutional tort plaintiffs are less successful than defendants, while non-civil-rights plaintiffs are marginally more successful than non-civil-rights defendants in reversing judgments. The view from published appellate opinions is that constitutional tort plaintiffs are less successful on appeal than other plaintiffs.

\section{Matters Appealed.}

There are two different ways of looking at the matters at issue in constitutional tort appeals. First, constitutional tort litigation may be broken down into many mutually exclusive subject areas, including actions against the police, discrimination claims, employment claims, First Amendment claims, and other areas. ${ }^{56} \mathrm{~A}$ second way of viewing matters appealed is to look at the legal doctrines at issue. Each constitutional tort case will involve not only one of the above subject areas, but will also involve at least one general legal doctrine, such as jurisdiction, evidence, periods of limitation, and the like. These doctrinal categories, unlike subject areas peculiar to constitutional tort litigation, cross boundaries between constitutional tort and other litigation. For example, both kinds of cases might involve an appeal from a ruling about a statute of limitations. To the extent discernible and comparable, how do the doctrinal issues on appeal in constitutional tort litigation differ from those in other litigation? Table II shows the relative frequency of appeal for several doctrinal categories, comparing nonprisoner constitutional tort cases with the control group.

ss Our study contains 111 published opinions where the prisoner constitutional tort plaintiff appealed and only 16 cases where the defendant appealed. The difference in reversal rates is statistically significant only at the .12 level.

s6 We discuss how constitutional tort litigation breaks down into these subject areas later. See text accompanying Table III. See also Theodore Eisenberg, Civil Rights Legislation 86-87 (Michie, 2d ed 1987). 
Table II

Comparing Matters Appealed in Constitutional

Tort and Other Litigation

\begin{tabular}{lccrrrrr}
\hline & \multicolumn{3}{c}{ Nonpris. Const. Tort } & \multicolumn{2}{c}{ Control Group } \\
& \multicolumn{2}{c}{$\%$ Appealed by } & \multicolumn{2}{c}{$\%$ Appealed by } \\
Subject of Appeal & Plain. & Def. & Either & Plain. & Def. Either \\
In forma pauperis & $<1 \%$ & $0 \%$ & $<1 \%$ & $<1 \%$ & $0 \%$ & $<1 \%$ \\
Abstention & $2 \% *$ & $2 \% *$ & $4 \%$ & $<1 \%$ & $<1 \%$ & $1 \%$ \\
Subject matter jurisd. & $10 \%$ & $2 \%$ & $12 \%$ & $8 \%$ & $3 \%$ & $10 \%$ \\
Personal jurisd. & $<1 \%$ & $0 \%$ & $<1 \%$ & $1 \%$ & $1 \%$ & $2 \%$ \\
Stat. of limitations & $7 \% *$ & $<1 \%$ & $7 \%$ & $4 \%$ & $<1 \%$ & $4 \%$ \\
Preclusion & $4 \% *$ & $1 \%$ & $4 \%$ & $2 \%$ & $1 \%$ & $2 \%$ \\
Discovery & $1 \%$ & $0 \%$ & $1 \%$ & $1 \%$ & $1 \%$ & $1 \%$ \\
Exhaustion of remedies & $3 \% *$ & $1 \%+$ & $4 \%$ & $1 \%$ & $<1 \%$ & $1 \%$ \\
Evidentiary ruling & $2 \%$ & $1 \%$ & $3 \%$ & $2 \%$ & $2 \%$ & $4 \%$ \\
Compens. damages & $1 \% *$ & $1 \%$ & $2 \%$ & $3 \%$ & $2 \%$ & $4 \%$ \\
Punitive damages & $1 \%$ & $1 \%$ & $2 \%$ & $1 \%$ & $1 \%$ & $2 \%$ \\
Fees award or size & $10 \% *$ & $5 \% *$ & $14 \%$ & $2 \%$ & $2 \%$ & $4 \%$ \\
Ruling on merits & $55 \%$ & $17 \% *$ & $69 \%$ & $50 \%$ & $33 \%$ & $78 \%$ \\
Venue & $1 \%$ & $<1 \%$ & $1 \%$ & $<1 \%$ & $<1 \%$ & $1 \%$ \\
& & & 604 & & & 760 &
\end{tabular}

* indicates significantly different from control group at at least .05 level (calculated only for plaintiff and defendant columns)

+ indicates significantly different from control group at at least .05 level before Yates Correction

Notes: Plaintiff and Defendant columns do not add up to "Either" column due to rounding and due to the fact that in some cases both plaintiff and defendant appeal an issue. Control group is weighted to reflect different proportions of non-civil-rights cases being sampled in the three circuits.

The Table suggests that constitutional tort opinions deal more often with procedural and other technical matters than do noncivil-rights opinions, but the difference is modest. Some 78 percent of the control group opinions address lower court rulings on the merits. Only 69 percent of the constitutional tort opinions deal with the merits. Fully 14 percent of the constitutional tort opinions address attorney fees, while only 4 percent of non-civil-rights opinions examine these issues. The greater frequency of attorney-feesrelated appeals is probably attributable to the right of a prevailing party to recover fees in civil rights cases. ${ }^{57}$ The differences in the

${ }^{87}$ See 42 USC $\S 1988$ (1982). 
rates of abstention and exhaustion-of-remedies appeals indicate their relatively larger role in civil rights cases. We also find statistically significant differences (at the .05 level) between constitutional tort plaintiff appeal rates and other plaintiff appeal rates in two other categories: statutes of limitations and preclusion.

In summary, constitutional tort litigation on appeal is not that different from other appellate litigation. Some of the differences are explainable by the number and nature of cases filed at the district court level and not by any phenomenon peculiar to the treatment of constitutional tort litigation on appeal. The two most distinctive features detected about constitutional tort litigation are its numeric prominence on the appellate filing docket and the relative lack of success for plaintiffs on appeal in comparison to defendants on appeal.

\section{B. Appellate Cases Compared with Filed Cases}

The snapshot of constitutional tort litigation in district court reveals, in important respects, a different picture than does the snapshot based on published opinions or appellate filings.

\section{Number of Cases.}

At the district court level for the three studied districts, nonprisoner constitutional tort cases comprised about 3 percent of the district courts' civil filing caseload, and prisoner constitutional tort cases comprised approximately 4 percent of the caseload. ${ }^{58}$ Applying the knowledge gained about the actual number of constitutional tort filings, we estimate that nationally in 1980-81 nonprisoner constitutional tort filings comprised 4.3 percent of the federal civil district court docket and prisoner constitutional tort filings comprised 8.1 percent. ${ }^{50}$ This suggests that the raw number

s8 Schwab \& Eisenberg, 73 Cornell $L$ Rev at 725 (cited in note 3).

so Our district court study yields an estimate of the percentage of district court filings in 1980-81 that are constitutional tort cases in each Administrative Office civil rights category. Schwab \& Eisenberg, 73 Cornell L Rev at 725 (Table I) (cited in note 3). We multiply these percentages times the number of cases the Administrative Office reports nationally in each category for that year to estimate a national number of actual constitutional tort cases. The percentage estimates and the filings, reported in Administrative Office of the U.S. Courts, 1981 Annual Report of the Director 366-367 (Table C2) (GPO, 1981), are: 
of constitutional tort filings is smaller than is generally believed. ${ }^{60}$ The published opinion study shows nonprisoner constitutional tort litigation comprising about 10 percent of the courts of appeals workload. This is a rate roughly three times higher than the percentage of nonprisoner district court filings in the three studied districts. Table I above offers further evidence of greater proportionate appellate-level constitutional tort activity. Administrative Office data reveal dramatic differences in the percentage of filings consisting of possible constitutional tort cases at the district court and appellate level. The combined percentage of prisoner/nonprisoner civil rights filings from 1982 to 1987 is about twice as high for appeals as it is for district court filings. The reader of published opinions or the observer of all appellate filings thus might conclude that constitutional tort litigation is substantially more voluminous than detailed inspection of district court filings indicates.

An especially large difference exists at the appellate level between the relative number of prisoner constitutional tort cases revealed by the published opinion study and the relative number of such cases suggested by Administrative Office filing data. Prisoner cases comprise only 2.7 percent of published opinions but about 12 percent of filings. This suggests that, despite the low number of opinions, it would not be surprising if appellate judges found prisoner cases to be a substantial part of their docket. Courts of appeals dispose of prisoner cases, more than other cases, on preliminary procedural grounds and without argument or published

\begin{tabular}{lrrr}
\hline & $\begin{array}{c}\text { percent } \\
\text { estimates }\end{array}$ & $\begin{array}{c}\text { filings } \\
\text { reported }\end{array}$ & \multicolumn{1}{c}{$\begin{array}{c}\text { filings } \\
\text { estimated }\end{array}$} \\
other civil rights & $74.0 \%$ & 8,433 & 6,240 \\
voting & $62.5 \%$ & 152 & 95 \\
jobs & $18.7 \%$ & 6,245 & 1,168 \\
accommodations & $27.3 \%$ & 336 & 92 \\
welfare & $69.2 \%$ & 253 & 175 \\
total nonprisoner & $89.0 \%$ & & 7,770 \\
prisoner civil rights & & 16,473 & 14,661
\end{tabular}

The Administrative Office also reports a total of 180,576 civil cases filed in 1980-81. Id. Multiplying the category figures by the corresponding percentages yields 7,770 estimated actual constitutional tort cases out of a total of 180,576 filings or 4.3 percent of the federal docket. In the prisoner civil rights category, the Administrative Office reports 16,473 filings. Id. If 89 percent of those were actual constitutional tort cases, the 89 percent times 16,473 or 14,661 out of 180,576 or 8.1 percent of the civil docket consisted of prisoner constitutional tort claims. Earlier higher figures reported in Schwab \& Eisenberg, 73 Cornell L Rev at 725 n 25 (cited in note 3), are erroneously based on the total cases figure for "actions under statutes" at the top of page 367 in the Administrative Office Report rather than on the true total figure at the top of page 366.

Bo Schwab \& Eisenberg, 73 Cornell L Rev at 724-25 (cited in note 3). 
opinion. For example, in fiscal 1986 what the Administrative Office labels "terminations on the merits" occurred in 53.9 percent of all appeals terminated but only in 47.1 percent of private prisoner petitions. ${ }^{61}$ And although 55.0 percent of terminated federal question cases received appellate oral hearings, only 12.2 percent of prisoner civil rights petitions were accorded oral hearings. ${ }^{62}$

\section{Success Rates.}

At the district level, constitutional tort litigation fares worse than most other litigation in almost every measurable respect. ${ }^{63}$ Nonprisoner constitutional tort plaintiffs secure judgments as the result of trials or motions in 5 percent of filed cases and obtain settlements (generously defined) in 45 percent of filed cases. ${ }^{64}$ Non-civil-rights plaintiffs succeed in court in 11 percent of filings and obtain settlements in 73 percent of filings. ${ }^{65}$ If one limits the universe of cases to those disposed of in court, thus eliminating settlements, the difference between constitutional tort and other litigation widens. Nonprisoner constitutional tort plaintiffs win only 9 percent of district court judgments, and prisoner constitutional tort plaintiffs win less than 1 percent of judgments. Noncivil-rights plaintiffs, by contrast, win 41 percent of district court judgments. ${ }^{66}$

No single number exists by which to compare the success rates of constitutional tort plaintiffs in district court and on appeal. Settlements play no significant numerical role in appellate litigation but are a major method of district court disposition. ${ }^{67}$ District court judgments are probably more concrete indicators of success than appellate judgments, where a victory may simply send the appellant back to district court. ${ }^{68}$ Further, comparing absolute num-

-1 Administrative Office of the U.S. Courts, 1986 Annual Report of the Director 155 (Table B-5) (GPO, 1986).

${ }^{62}$ Id at 142 (Table B-1A).

6s Schwab \& Eisenberg, 73 Cornell L Rev at 728-30 (cited in note 3).

os Id at 733 (Table IV).

so Id.

6 Figures obtained by calculations based on data from id at 733 (Table IV).

s7 Id.

6s Successful appeals are those in which the plaintiff obtains reversal of an adverse ruling below. An appellate court reversing an unfavorable ruling below often is not awarding the constitutional tort plaintiff anything. At the district court level, however, successful cases are those in which plaintiffs actually recover something. Thus the nature of the appellate process might lead to a natural increase in the apparent success rates of groups of plaintiffs that fare poorly below. Success is in some sense easier to achieve on appeal and this might explain some of the reduced gap between constitutional tort and control group 
bers is always problematic when they are derived from different data sets-in this case, our district court study of filed cases and our appellate study of published opinions. Thus, one must hesitate before declaring that constitutional tort plaintiffs appear relatively more successful on appeal than in district court.

Although one must acknowledge the different possible yardsticks of success, recall that we are most interested in the perspectives of different observers. Whether or not a successful appeal is as "real" a victory as is a win at trial, the appellate observers see mostly what goes on in appellate cases. They of course know that some reversals and remands won't lead to a recovery on remand, but their scorecards of wins and losses are maintained in terms of the possibilities at the appellate level. To them a reversal at the intermediate stage of proceedings is a victory for plaintiffs because it at least gives the plaintiff a chance of ultimate recovery.

With these qualifications in mind, by any measure of success constitutional tort plaintiffs appear more similar to other plaintiffs (and thus appear more successful) on appeal than in district court. As Figure 2 shows nonprisoner constitutional tort plaintiffs succeed in 38 percent of the cases they appeal that lead to opinions. Non-civil-rights plaintiffs succeed in 35 percent of such cases. Defendants in nonprisoner constitutional tort litigation succeed in their appeals 48 percent of the time. Defendants in non-civil-rights cases succeed 33 percent of the time. Whether one examines only district court judgments or includes settled cases, the gap between nonprisoner constitutional tort litigation and other litigation appears greater than the relatively modest disparity in published appellate opinions.

\section{Subject Matter.}

Although some constitutional claims cannot give rise to constitutional tort actions, ${ }^{69}$ the vast bulk of constitutional wrongs are cognizable under $\S 1983^{70}$ or Bivens. ${ }^{71}$ The variety of possible con-

cases. For example, even though plaintiff-appellant success rates are higher for prisoners than for nonprisoners, see Figure 2 supra, they may be succeeding simply in obtaining reversal of pretrial motions to dismiss their cases. Such appellate victories may not result in ultimate success for the plaintiff.

${ }^{69}$ See Schweiker v Chilicky, 108 S Ct 2460 (1988) (no Bivens action); Bush v Lucas, 462 US 367 (1983) (no Bivens action); Consol. Freightways Corp. of Del. v Kassel, 730 F2d 1139 (8th Cir 1984) (no § 1983 claim).

${ }^{70}$ See, for example, Monroe v Pape, 365 US 167 (1961).

${ }^{71}$ See, for example, Carlson v Green, 446 US 14 (1980); Davis v Passman, 442 US 228 (1979); Butz v Economou, 438 US 478 (1978). 
stitutional tort claims suggests peering within the constitutional tort category. How does the subject matter of constitutional tort litigation shift when one moves from district court filings to published appellate opinions? Table III subdivides constitutional tort litigation by subject matter and presents success rates within each category. ${ }^{72}$

\section{Table III}

Success and Number of Appellate \& District

Court Constitutional Tort Cases

by Kind of Case

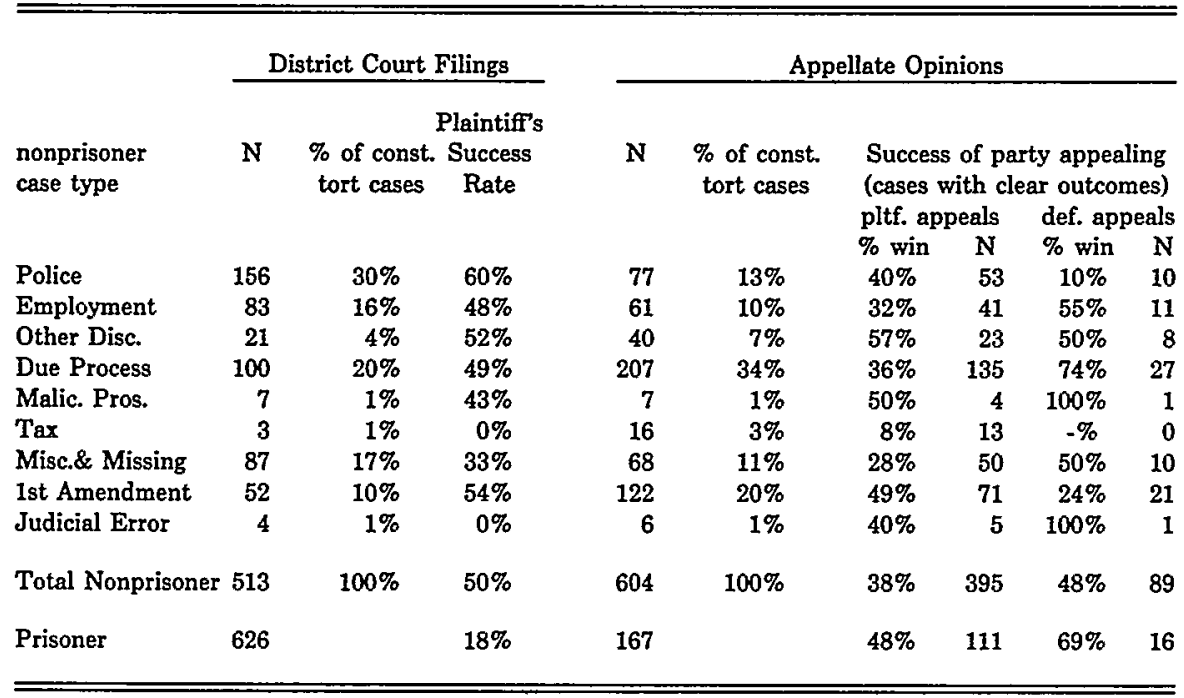

At the district court level, police misconduct cases accounted for almost one-third of filed nonprisoner cases. Discrimination claims (the "Employment" and "Other Discrimination" categories) accounted for about 20 percent of filed cases. First Amendment claims were a mere 10 percent of filings. Prisoners filed more constitutional tort cases than did nonprisoners. From the perspective of published appellate opinions, matters change dramatically. Police-related claims fall to about 13 percent of published opinion cases and the percentage of employment discrimination claims drops considerably as well. In contrast, the proportion of due process claims rises substantially and First Amendment claims on appeal appear twice as often as in the district court filings.

The relative success of constitutional tort categories also is re-

72 The subject matter categories in Table III are mutually exclusive. We recognize that some cases do not comfortably fit into only one category. 
shuffled on appeal. ${ }^{73}$ At the district court level, police, First Amendment and other discrimination claims were the most successful areas of constitutional tort litigation, but all the large categories had similar success rates. In published appellate opinions, First Amendment claims clearly outpace police and employment discrimination claims in terms of the plaintiff's success rate as appellant. ${ }^{74}$ Even more noticeable is the increased success of prisoner cases, which looked uniformly unsuccessful at the district court level. Appeals brought by prisoners are one of the most successful categories of cases, and would be more so if the 10 unsuccessful parole and probation proceedings were excluded (none was successful). ${ }^{75}$

\section{District Courts Viewed Through Published Appellate Opinions}

Comparison of constitutional tort litigation on appeal with constitutional tort litigation at the district court level suggests that observers of these two branches of the federal court system would have different impressions of constitutional tort litigation. For many observers of the litigation system, however, there is an air of unreality about our district court perspective. Although our prior work provides detailed data about district court filings and dispositions, most observers lack such information. Their information about activity at the district court level comes, as it does in most traditional law school courses, from information conveyed by published appellate opinions.

One concerned about how impressions of litigation reality are formed and vary could pose the following questions: What does district court constitutional tort litigation look like when viewed through the lens of published appellate opinions? How does that picture differ from what one sees about district court level activity when more complete information is available? The basic question here differs from that pursued in the previous section. That section asked how actual characteristics of appellate work (as reflected in

${ }^{73}$ The appellate success columns in the table exclude cases with ambiguous outcomes on appeal and thus have lower totals than the other columns.

74 The need to distinguish between a litigant's status as appellant and appellee complicates assessing overall success at the appellate level. See text at notes 54-55.

${ }^{75}$ Excluding the 10 unsuccessful prisoner probation and parole cases would show prisoners succeeding in 53 percent of the cases in which they appealed, higher than all nonprisoner plaintiff appeal success rates in Table III except the plaintiff appeal success rate in the "other discrimination" cases (a small number of cases). In contrast, prisoners as appellees fare rather poorly, losing 69 percent of the cases in which the defendant appeals (a 31 percent prisoner-appellee success rate). 
published opinions) differ from the actual characteristics of district court activity (as reflected in district filings). It compared snapshots of two different levels of the federal court system. The focus now is only on the district court level, but using two different pictures of it. One picture is of district court reality as reflected in the district court filings study; the other is of district court activity as reflected in appellate opinions. The two pictures of the same subject differ substantially. The appellate filtering process distorts both the procedural dispositions and the success rate.

Note that only certain comparisons are available. One cannot compare how the bulk of filed cases fare at the district court and appellate levels because only a small fraction of any class of cases rises to the appellate level. The federal court system has over 200,000 district court civil filings and about 25,000 appeals from those filings. ${ }^{76}$ The bulk of filings do not exist at the appellate level and no direct information about them can be contained in appellate opinions. In particular, the large chunk of litigation that ends in settlement virtually disappears at the appellate level. Nevertheless, several characteristics of district court litigation can be discerned through the appellate lens. How much distortion does that lens introduce and is the distortion in a direction that helps explain the differences in perceptions about constitutional tort litigation?

\section{Success of Tried Cases Viewed from Appeal.}

Tried cases provide one area in which success at the district court level can be viewed from both the appellate and district court perspectives. In district court cases litigated to trial, earlier work shows that plaintiffs prevail in 27.4 percent of nonprisoner constitutional tort cases, 18.5 percent of prisoner constitutional tort cases, and 56.3 percent in the control group of non-civil-rights cases. ${ }^{77}$ Nonprisoner constitutional tort plaintiffs thus do roughly half as well at trial as non-civil-rights plaintiffs, and prisoners do one-third as well. In tried district court cases leading to published appellate opinions, by contrast, constitutional tort plaintiffs prevailed at trial at the district court level in 135 of 251 (54 percent) cases, a rate more than double that found at the district court level. In the group of non-civil-rights cases with published opin-

${ }^{76}$ Administrative Office of the U.S. Courts, 1987 Annual Report of the Director 108-09 (Tables S-6 \& S-8) (GPO, 1987).

${ }^{77}$ Schwab \& Eisenberg, 73 Cornell L Rev at 729 n 37 (cited in note 3). 
ions, plaintiffs prevailed in 178 of 194 (61 percent) cases, a rate not significantly different from that of tried district court successes. Impressions of the legal system shaped by published opinions thus would tend to overestimate the trial success rate of constitutional tort plaintiffs. Indeed, at the appellate level their trial success rate is not statistically distinguishable from the success rate of other litigation. At the district court level, constitutional tort plaintiffs fare much worse. Yet for the control group there is a close match between the trial success rate found in the district court study and the rate obtained by observing only published opinions.

\section{Procedural Progress.}

The published appellate opinion snapshot of district court proceedings shows cases reaching trial in 33 percent of nonprisoner constitutional tort cases and 25 percent of prisoner cases, and 39 percent of control group cases. Study of filings at the district court level shows trials commencing in $\mathbf{1 5}$ percent of nonprisoner cases, 5 percent of prisoner constitutional tort cases and 10 percent of control group cases. ${ }^{78}$ To some, the more appropriate district court comparison might not be the universe of all filed cases but the group of district court filings resolved in court, thereby excluding settlements. Limiting study to in-court dispositions, calculations using results from our prior work show that nonprisoner constitutional tort cases reach trial in 76 of 280 (27 percent) cases, prisoner constitutional tort cases reach trial in 31 of 520 (6 percent) cases, and control group cases reach trial in 65 of 176 (37 percent) cases. $^{79}$

Analysis of these data uncovers two distortions in the appellate lens. First, though the district court filings establish that nonprisoner constitutional tort cases have trial rates greater than other litigation, constitutional tort cases appear to have trial rates lower than other litigation if one looks at the universe of cases resolved other than by settlement, or at published appeals. Second, the observer of published opinions would see prisoner case trial rates relatively higher than would the observer of either universe of district court cases.

\section{Fiscal Impact.}

Table IV shows the fiscal characteristics of cases at the district

${ }^{78}$ Schwab \& Eisenberg, 73 Cornell L Rev at 733 (Table IV) (cited in note 3).

${ }^{78}$ These calculations are based on figures at id and exclude settled cases. 
and appellate levels. The district court study showed recovery of a money judgment in 2 percent of nonprisoner constitutional tort cases filed and in 10 percent of the control group cases filed. $.^{80} \mathrm{Pub}-$ lished appellate opinions reveal money judgments in 70 of 604 (11.6 percent) nonprisoner constitutional tort cases and in 19.6 percent of control group cases filed. Thus, the intergroup ratio of money judgments is 5 to 1 at the district court level and less than 2 to 1 at the appellate level, and within the group of nonprisoner constitutional tort cases, money judgments show up in opinions more than five times as frequently as they show up in filed cases.

\section{Table IV}

Fiscal Characteristics:

Constitutional Tort \& Other Litigation, District Courts \& Published Opinions

\begin{tabular}{|c|c|c|c|c|}
\hline Frequency of Mo & \multicolumn{2}{|c|}{$\begin{array}{l}\text { Nonprisoner } \\
\text { Constit. Tort }\end{array}$} & \multicolumn{2}{|c|}{$\begin{array}{l}\text { Control Groups } \\
\text { W/O Defaults }\end{array}$} \\
\hline $\begin{array}{l}\text { dist. court filings } \\
\text { published opinions }\end{array}$ & $\begin{array}{l}N \\
13 \\
70\end{array}$ & $\begin{array}{r}\% \\
2 \% \\
11.6 \%\end{array}$ & $\begin{array}{r}\mathrm{N} \\
57 \\
149\end{array}$ & $\begin{array}{r}\% \\
10 \% \\
19.6 \%\end{array}$ \\
\hline \multicolumn{5}{|c|}{ Size of Money Judgments (Dollars) } \\
\hline $\begin{array}{l}\text { dist. court filings } \\
\text { mean } \\
\text { median }\end{array}$ & $\begin{array}{l}\mathrm{N}= \\
53, \\
55,\end{array}$ & & $\begin{array}{r}\mathrm{N}=194 \\
32,903 \\
3,110\end{array}$ & $\begin{array}{l}\text { w/o defaults } \\
\mathrm{N}=57 \\
77,095 \\
17,500\end{array}$ \\
\hline $\begin{array}{l}\text { published opinions } \\
\text { mean } \\
\text { median }\end{array}$ & $\begin{array}{l}\mathrm{N}= \\
54, \\
26,\end{array}$ & & $\begin{array}{r}N=73 \\
411,297 \\
67,363\end{array}$ & \\
\hline
\end{tabular}

If we exclude settlements from district court filings and examine only cases resolved in court, the relative frequency of money judgments for constitutional tort plaintiffs decreases even more. Nonprisoner constitutional tort plaintiffs obtain money judgments in 10 of 280 (3.6 percent) cases, prisoner constitutional tort plaintiffs obtain money judgments in about 1 percent of 520 cases, and control group plaintiffs obtain money judgments in 65 of 176 (37 percent) cases. $^{81}$ Under both measures of district court recovery

so Schwab \& Eisenberg, 73 Cornell L Rev at 733 (Table IV) (cited in note 3). We emphasize that the money judgment figures merely reflect what appears in court records. They do not necessarily account for all money transfers in the studied cases.

81 These calculations are based on figures in id. The district court control group figure 
rates, constitutional tort litigation, viewed through published appellate opinions, looks (1) much more like other litigation and (2) much more successful than it does when viewed from the perspective of district court filings.

The size of monetary awards also differs substantially when viewed from the appellate level. Unfortunately, the low absolute number of district court monetary recoveries affects the certainty of our conclusions here. Settlements, more than money judgments, probably shape the fiscal impression of district court litigation. Nevertheless, in nonprisoner constitutional tort cases the median district court award is twice the size of the median district court award in published opinions, contrary to the usual trend of appellate litigation showing greater success and sizes of awards. The relationship between the control group and constitutional tort categories is also interesting. On appeal we find what one might expect: the amount awarded in constitutional tort cases is dwarfed by appellate awards in other classes of cases. But at the district court level, even excluding the many default judgment cases, the few constitutional tort cases that achieve money judgments hold up quite well in size compared to the control group.

\section{The Different Perspectives on Constitutional Tort Litigation}

Today there exist two fundamentally different impressions of constitutional tort litigation. One is the general impression, described by us elsewhere, ${ }^{82}$ of numerous successful constitutional tort cases imposing massive monetary costs on state and local governments. The other is the impression, supported by our district court study, of relatively fewer cases meeting with poor success and having a modest fiscal impact. ${ }^{83}$ It is instructive to compare these two real-world impressions of constitutional tort litigation with the different perspectives of our three hypothetical observers of the legal system.

in text (65 of 176) differs from the 57 control group money judgments shown in Table IV. The table uses only the 57 cases in which the amount of a money judgment is known (as opposed to the fact of its existence). The 65 of 176 figure includes 8 other cases in which we know there was a money judgment, but we do not know the amount. In Table IV, we evaluate amounts of judgments and therefore are limited to cases with known dollar figures.

${ }^{82}$ See Eisenberg \& Schwab, 72 Cornell L Rev at 644-52 (cited in note 3); Schwab \& Eisenberg, 73 Cornell $\mathrm{L}$ Rev at $720 \mathrm{n} 2$ (cited in note 3).

${ }^{83}$ See Eisenberg \& Schwab, 72 Cornell L Rev at 658-92 (cited in note 3); Schwab \& Eisenberg, 73 Cornell L Rev at 723-39 (cited in note 3). 


\section{A. Different Information Explains Different Impressions}

Our first observer is the idealized law professor, able to read and synthesize every published appellate opinion. The professor sees that nonprisoner constitutional tort cases make up about 10 percent of all cases and that prisoner cases account for roughly an additional 3 percent. A constitutional tort plaintiff is as successful in overturning a judgment below as are other plaintiffs. Impressively, even prisoner constitutional tort plaintiffs are reasonably successful in overturning judgments. The major difference between constitutional tort and other litigation is that constitutional tort plaintiffs cannot hold judgments on appeal. Constitutional tort defendants (governments and their officials) overturn half the judgments they appeal in nonprisoner cases, while defendants in other cases, like most plaintiffs, succeed in overturning only about 35 percent of the judgments against them. District court judgments favoring prisoners are even more likely to get reversed. While relatively few judgments favoring prisoners are discussed in published opinions ${ }^{84}$ appellate courts reverse them two-thirds of the time. The professor also finds that nonprisoner constitutional tort plaintiffs obtain money judgments in about 12 percent of the reported cases. ${ }^{85}$ Constitutional tort cases take about as long to decide, and nonprisoner cases generate more concurring and dissenting opinions.

To the professor, prisoner cases do not differ dramatically from nonprisoner cases, except that there are far fewer of them and the judgments below are less stable. Prisoners appealing adverse judgments below are somewhat more successful than nonprisoner constitutional tort plaintiffs (as well as non-civil-rights plaintiffs). Prisoners seem to have greater difficulty in having favorable judgments affirmed on appeal, but there are too few cases for the professor to be confident of this. Prisoner cases take about as long and spur as many dissents but somewhat fewer concurrences.

The professor realizes that published appellate opinions give a window on district court activity. Gazing through this window, the professor sees that about the same percentage of constitutional tort cases go to trial and succeed as do other classes of cases. Con-

B4 Recall that our brilliant professor reading every published opinion in the Third, Ninth, and Eleventh Circuits from 1980-85 could find only 16 cases where a prisoner constitutional tort plaintiff had prevailed below. See note 55. Ten of those judgments were reversed on appeal.

ss See Table IV. 
stitutional tort litigation looks like it yields money judgments reasonably frequently though only about half as frequently as other litigation.

The idealized appellate judge has a different vantage point, observing all appeals, not just the ones leading to published opinions. Importantly, the appellate judge sees far more prisoner appeals, comprising about 14 percent of the overall appellate civil docket (not including cases from agencies). Because our study does not include an examination of the outcome of all filed appeals, we do not know what the appellate judge thinks about the overall success rate or size of awards of all constitutional tort appeals.

Finally, the district judge sees a dramatically different picture. Most important, is that the bulk of cases are privately settled rather than decided by the court. Nonprisoner constitutional tort cases constitute a smaller fraction of litigation, only about 4 percent. Prisoner constitutional tort cases far outnumber nonprisoner constitutional tort cases. ${ }^{86}$ While settlement is the main method of disposing of non-civil-rights cases (fully 73 percent settling), less than half ( 45 percent) of the nonprisoner constitutional tort cases settle and only 17 percent of prisoner constitutional tort cases settle. ${ }^{87}$ Thus, constitutional tort cases are resolved more frequently by district court judgments than are other cases. Along with this, nonprisoner constitutional tort cases comprise much higher than normal percentages of district court hearings and trials.

In short, the perspectives differ in important respects. The district court judge sees a lower percentage of constitutional tort filings, but the cases settle less frequently, take up more court time, yet win disproportionately fewer judgments. The appellate judge sees a higher fraction of constitutional tort filings. And the professor reading appellate opinions sees a substantial number of constitutional tort cases that are reasonably successful. Together, the different perspectives suggest that there is no single, correct description of constitutional tort litigation. ${ }^{88}$ Our admittedly ideal-

${ }^{86}$ Our analysis focuses on constitutional tort litigation and separates out habeas corpus cases filed by prisoners. A district judge who lumps all prisoner cases together, would find that prisoners occupy a substantially larger fraction of the civil docket. See the Annual Reports cited in note 40 . See also Eisenberg \& Schwab, 72 Cornell L Rev at 665, 667 (Tables II and IV) (cited in note 3).

${ }_{87}$ Schwab \& Eisenberg, 73 Cornell L Rev at 733 (Table IV) (cited in note 3). The settlement estimates from the earlier study should be regarded as upper limits on the settlement rates. In that study we employed a generous definition of successful settlement to avoid understating the success of constitutional tort litigation. Id at 726-27.

${ }_{88}$ The one conclusion common to all viewers is that constitutional tort plaintiffs are less successful than other plaintiffs. 
ized judges and commentators are not interpreting the same information in a radically different manner. They are seeing different information about the system.

\section{B. Why Might One Impression Dominate?}

If there is no single correct view, and if the district court reality is every bit as (if not more) reflective of constitutional tort activity as the appellate perspectives, one further question arises. Despite this variety of possible viewpoints about constitutional tort litigation, those bothering to write about it share a more uniform vision-that of many more cases, and many more successful cases, than the district court experience suggests. One might expect more observers to write about how surprisingly few (relative to common perceptions) constitutional tort cases there are and how uniformly unsuccessful the cases are. Why is there this asymmetry in expressed views given the richer mix of possible viewpoints reflected in the data about constitutional tort litigation?

Consider the observer of published opinions who also knows or reads about the great number of prisoner cases filed. This observer, who has the characteristics of many real world observers, would read about prisoner litigation in published opinions and observe a class of modestly successful litigation. The observer's knowledge of many prisoner filings might lead to unconsciously attributing the published opinion success rate to the mass of prisoner litigation, thereby enormously increasing, in the observer's mind, the raw number of successful prisoner cases. Direct observation of actual district court activity would quickly dispel this impression.

In the nonprisoner context, the observer would make the same error. By any account there are many constitutional tort filings. ${ }^{88}$ The observer might apply the success rate in published opinions to all nonprisoner litigation. The observer might well conclude, with some confidence, that there are abundant numbers of successful constitutional tort cases. And although the mean award in such cases seems low compared to other litigation, it is, when combined with a success rate inflated by the appellate perspective, high enough in an absolute sense to raise concern about the fiscal consequences of constitutional tort litigation.

In both the prisoner and nonprisoner contexts, the observer

82 Our findings that constitutional tort litigation is less frequent than many believe and our questioning the existence of a recent explosion in constitutional tort litigation, see text at note 3 , do not mean that constitutional tort cases are an insubstantial part of federal litigation. 
takes information from the most readily available cases, published opinions, and applies it to the universe of nonobservable cases, district court filings. ${ }^{90}$ The cases for which information is most readily available thereby dominate and inflate the real world observer's estimate of constitutional tort litigation's success throughout the system.

The skewing towards overstating the impact of constitutional tort litigation receives important reinforcement from the "big case" phenomenon at the district court level. For even though it is at the district court level that constitutional tort litigation seems numerically least frequent and least successful, the district courts handle a highly visible class of cases that are not representative of constitutional tort litigation as a whole.

Many people know little about what goes on in the district courts other than what they read about large scale institutional cases involving prisons, hospitals, and school systems. These cases, though numerically a small fraction of the docket, manage to dominate local headlines, make national news, comprise the subject of entire law school casebooks, and occupy many commentators. They are important, complex, long-lasting, and controversial. If one's major source of information about constitutional tort litigation consists of newspaper and scholarly accounts of institutional cases, and one succumbs to the illusion that what one observes is representative of what one does not see, ${ }^{91}$ constitutional tort litigation again will be perceived as more burdensome and significant than it actually is.

\section{Explaining Appellate-District Court Differences}

Three elements of the appellate and district perspectives stand out. First, both appellate opinion readers and district court

${ }^{80}$ Tversky and Kahneman argue that an observer "attempts to construct some instances and judges overall frequency by availability, that is, by an assessment of the ease with which instances could be brought to mind." Amos Tversky \& Daniel Kahneman, Availability: A Heuristic for Judging Frequency and Probability, in Daniel Kahneman, Paul Slovic \& Amos Tversky, eds, Judgment under Uncertainty: Heuristics and Biases 166 (Cambridge, 1982). Consequently, they continue, instances that are easily recalled will be perceived as occurring more frequently than instances that are less readily available. They term this the availability heuristic. Applying the appellate success rate to the large class of district court filings also implicates what Twersky and Kahneman refer to as "representativeness." Think of all cases as a class and appellate litigation as a subset of the class. Our observer may be giving appellate litigation too much credence as a representative of all litigation. See, for example, Amos Tversky \& Daniel Kahneman, Judgments of and By Representativeness, in id at $84,86$.

${ }^{91}$ See generally Tversky \& Kahneman, Part II: Representativeness, in id at 23-98. 
observers see that constitutional tort plaintiffs are significantly less successful than other federal court plaintiffs. Second, this difference in success rates is less dramatic at the appellate level than at the trial level. Finally, constitutional tort cases are a much higher percentage of appellate opinions than they are of district court filings.

It is not surprising that published opinions offer a different perspective on constitutional tort litigation than do district court filings. Parties do not randomly decide which cases to settle and which to continue through to district court judgment. ${ }^{92}$ Nor do they randomly appeal these judgments. Nor do judges randomly decide which of these appeals to publish. This filtering process, as we shall call it, makes appellate opinions a biased sample of district court filings. If the filtering process differs between constitutional tort cases and other cases, this could explain why the relative comparisons between constitutional tort and other litigation differ on appeal and at the district court level.

\section{The Publication Filter.}

Consider first the decision by appellate judges to publish opinions, while assuming that the rest of the filtering process is the same for constitutional tort cases and other cases. Judges themselves decide whether to publish an opinion. The general criterion for publication is that the case be noteworthy rather than routine or obvious, and thus will contribute to the development of the law. Certainly, cases where district court judges are found "wrong" would often fit this criterion. One would expect, then, that most reversals would be published, as well as non-routine affirmances. This filtering effect of the criterion for publication would tend to increase the number of reversals found in published opinions over the actual number of reversals from all appeals. But this filter, without more, would be uniform across all classes of litigation and between plaintiffs and defendants. It does not explain the disproportionate number of published opinions reversing judgments for constitutional tort plaintiffs. Only if the law is becoming harsher toward constitutional tort plaintiffs would the publication filtering effect result in a disproportionately high number of reversals against successful plaintiffs.

Perhaps the reason constitutional tort plaintiffs are less successful appellees than other plaintiffs lies in differing receptivity of

92 Priest \& Klein, $13 \mathrm{~J}$ Legal Stud at 4 (cited in note 17). 
district and appellate judges towards constitutional tort cases. Appellate judges may be publishing a high number of opinions reversing lower court judgments for constitutional tort plaintiffs because they are attempting to change the law. This has a ring of plausibility in light of the time period covered by the study: appellate decisions rendered from October 1980 to December 1985. The district court decisions studied are clustered in the first year of this period. Thus, increasing numbers of Reagan appellate appointees would be reviewing earlier judgments of district court judges-and common speculation suggests they would view constitutional tort claims more critically. ${ }^{93}$

That appellate judges in the early 1980 s were attempting to change constitutional tort law might also explain the relatively high fraction of the published opinions devoted to constitutional tort appeals in general. If an area of law is stable, a case applying this settled law to particular facts is relatively unlikely to be worthy of publication. By contrast, if the substantive constitutional law is changing during a period, one might expect more published opinions.

\section{The Government as Defendant on Appeal.}

Other parts of the filtering process may also lead to different perspectives on constitutional tort litigation. In prior work we have suggested that since the government is always the defendant in constitutional tort litigation, constitutional tort plaintiffs may be less successful than plaintiffs in other cases. Two aspects of the government as defendant, both stemming from the government's position as a repeat player in litigation, seemed particularly critical. First, government defendants may have higher stakes in litigation, relative to plaintiffs, than do other defendants. If so, constitutional tort defendants will settle more cases, especially strong cases

83 Rigorous support for this explanation must await more detailed inquiry into the background of judges, an exploration we have begun in Theodore Eisenberg \& Stewart J. Schwab, The Influence of Judges and Their Backgrounds in Civil Rights and Prisoner Cases (unpublished manuscript, February 1989). See generally Stuart Taylor, Jr., The OnePronged Test for Federal Judges: Reagan Puts Ideology First in Filling Vacancies, NY Times E5 (April 22, 1984); Note, All the President's Men? A Study of Ronald Reagan's Appointments to the U.S. Court of Appeals, 87 Colum L Rev 766 (1987); C. K. Rowland, Robert A. Carp \& Donald Songer, The Effect of Presidential Appointment, Group Identification and Fact-Law Ambiguity on Lower Federal Judges' Policy Judgments: The Case of the Reagan and Carter Appointees, paper presented at the American Political Science Association Meeting, New Orleans, Aug 29 - Sept 1, 1985. 
for the plaintiff, rather than risk trial. ${ }^{94}$ Second, plaintiffs may have greater difficulty in predicting case outcomes when suing the government, while government litigators obtain expertise through experience. The differential ability to assess the strength of the case may lead to fewer settlements and to plaintiffs bringing weaker cases to trial. ${ }^{95}$

The impact on success rates of differing stakes is intensified on appeal, where the case may become a general precedent. The State of Pennsylvania, for example, must worry about the precedential effect throughout Pennsylvania if it loses an appeal from the Eastern District of Pennsylvania in a case involving state police. In many cases (but certainly not all), the constitutional tort plaintiff has less concern with circuit-wide precedent. Because of their concern with precedent, governments will be more cautious than plaintiffs in appealing judgments that are likely to be upheld. They will have a greater tendency to appeal only clear errors or other cases that are likely to be overturned. For plaintiffs, the possibility that the judgment will be affirmed is less likely to alter the decision to appeal because it affects fewer dollars. Thus, constitutional tort defendants are more likely to obtain reversals on appeal than are constitutional tort plaintiffs.

The impact on success rates of differential accuracy in assessing claims, by contrast, is likely to be reduced on appeal. William Baxter suggests that as more information about each party's position is disclosed, the plaintiff's and defendant's estimates of the likelihood of success should grow closer. ${ }^{96}$ With both their own assessments and the district judge's rulings as guidance, the parties should have comparable expectations as to the outcome. Additionally, the issues on appeal often differ from the issues at trial in ways leading to more similar assessments by the parties. For example, at trial a common issue is whether the jury will respond favorably to some evidence. Once the jury has decided, however, the issue on appeal is whether a rational jury could rule as this jury did. Usually this question is easier for lawyers to assess. The comparable predictions by both parties should lead to settlement in most cases. Only the most uncertain cases will be appealed. This factor would thus tend to push all appellate success rates towards 50 percent and explain why constitutional tort appellate success

4 Schwab \& Eisenberg, 73 Cornell L Rev at 752-55 (cited in note 3).

9s Schwab \& Eisenberg, 73 Cornell L Rev at 750-52 (cited in note 3).

96 William Baxter, The Political Economy of Antitrust, in Robert D. Tollison, ed, The Political Economy of Antitrust: Principal Paper by William Baxter 3, 15 (Lexington, 1980). 
rates are closer to those of the control group than are constitutional tort district court success rates.

Even though higher than district court success rates, constitutional tort appellate success rates may not rise to the level of other cases because the increased information effect may not apply equally to all cases. The parties' mutual assessment of case outcomes may be cloudier, even after trial, in constitutional tort cases than in other cases. Those who think First Amendment and Due Process cases are particularly difficult to resolve find support for this view in these cases' greater share of the appellate docket. ${ }^{97}$ Greater difficulty in assessing case law in constitutional tort cases may also explain why appellate judges see a higher proportion of constitutional tort cases than do district judges. Litigation models suggest that areas of greater doctrinal difficulty lead to higher litigation and appeal rates. ${ }^{98}$

\section{The Constitutional Tort Plaintiff on Appeal.}

Constitutional tort plaintiffs may have different litigation goals and settlement strategies than other plaintiffs. This difference might mean that plaintiffs will appeal adverse verdicts with less regard for the expected payoff on appeal. Obviously, this strategy could lead both to lower success rates than in other appealed cases and to constitutional tort cases being a higher fraction of the appellate docket.

One way to test this hypothesis is to examine the stakes of constitutional tort cases, relative to other cases, at the district court level and on appeal. All theories of which we are aware, as well as common sense, suggest that the cases pursued most vigorously by the parties (through trial and appeal) will be cases with relatively higher stakes than cases that are resolved at more preliminary procedural stages.99 This is because pursuing cases through the system increases the parties' costs and the increased costs can be expected to be recovered only in higher stakes cases. One also expects judges to feel more pressure to publish opinions in cases involving higher stakes than in less monetarily important cases. Thus, published opinions probably do not understate the av-

\footnotetext{
${ }^{97}$ See Table III for the fraction of constitutional tort cases by subcategory.

98 For example, Professors Priest and Klein project greater litigation rates in areas of greater uncertainty. Priest \& Klein, $13 \mathrm{~J}$ Legal Stud at 4 (cited in note 17).

${ }^{89}$ John P. Gould, The Economics of Legal Conflicts, 2 J Legal Stud 279 (1973); Richard Posner, Economic Analysis of Law $\$ 21$ (Little, Brown, 3d ed 1986); Priest \& Klein, $13 \mathrm{~J}$ Leg Stud 1 (cited in note 17).
} 
erage recovery in appealed cases.

The control groups bear out the theoretical prediction of higher monetary stakes in cases that the parties are willing to press to appeal. As Table IV shows, the mean and median recovery as viewed through published opinions far exceeds the mean and median recovery as viewed through district court money judgment cases. In nonprisoner constitutional tort cases, however, the predicted relationship between appellate level and district court money judgments is reversed. ${ }^{100}$ The table shows the median award as reflected in published opinions is only about one-half the median award in district court money judgment cases. What could explain this surprising result? Perhaps it is evidence that constitutional tort plaintiffs are less motivated by a cost-benefit calculus than are other litigants in deciding whether to appeal. ${ }^{101}$

\section{Conclusion}

It is clear that observers differ in their perceptions of constitutional tort litigation. Some perceive massive amounts of litigation burdening governments. Others perceive much frivolous litigation. Still others see smaller numbers of modestly successful cases. A cynical explanation of the exaggerated perceptions is that some have an agenda other than describing reality. The more catastrophic constitutional tort litigation can be made to appear, the better the chance of curtailing it. But the perception of voluminous, effective constitutional tort litigation is too widespread for a wholly skeptical explanation. This article has suggested that the cases observed affect the perception of constitutional tort litigation. Readers of published appellate opinions perceive a high percentage of successful constitutional tort cases. Those tracking the outcome of district court cases see a far different reality. It is comforting that our data suggest that people acting in utmost good faith can have such differing views of the system.

${ }_{100}$ Prisoner opinions revealed money recoveries in only eleven cases (ten of which were reversed on appeal), too few to allow meaningful comparisons with other types of cases.

${ }^{101}$ Aside from the possible freakishness of the small sample, another possibility is that the parties assess the cases in which constitutional tort plaintiffs obtain large money judgments in the district court to be very strong. All litigation exhibits a positive relationship between the size of the award and the objective strength of the case: a jury simply does not award a major monetary victory unless the case is also very strong on the merits. Perhaps this correlation is stronger in constitutional tort litigation. If the defendant believes this, it will not press an appeal. The remaining cases on appeal, then, will have lower stakes than the district court cases. 
